\title{
Calcium requirement and vitamin $D$ supplementation in meat-type quail at second stage of growth
}

\author{
Taynara Prestes Perine1, Simara Márcia Marcato1, Antonio Claudio Furlan1, Daiane de \\ Oliveira Grieser ${ }^{1}$, Vittor Zancanela1', Caroline Espejo Stanquevis¹, Mariani Ireni Benites', \\ Tainara Ciuffi Euzébio'
}

\begin{abstract}
${ }^{1}$ Universidade Estadual de Maringá, Departamento de Zootecnia, Maringá, PR, Brazil.
ABSTRACT - An experiment was conducted to determine the required levels of supplementary vitamin D and calcium in meat-type quail (Coturnix coturnix sp) between 15 and 35 days old. The experiment was a $4 \times 4$ factorial design with four levels of calcium: $0.42,0.58,0.74$, and $0.90 \%$ and four levels of vitamin D: 1,000; 2,000; 3,000; and 4,000 IU. Body weight and body weight gain increased linearly and feed conversion showed some linear improvement due to increased levels of Ca and vitamin D. The increased vitamin D levels resulted in a linear increase in feed intake. Calcium and vitamin D requirements in meat-type quail between 15 and 35 days of age is greater or equal to $0.90 \% \mathrm{Ca}$ and greater or equal to $4,000 \mathrm{IU}$ of vitamin $\mathrm{D}$, probably because the experiment was conducted during the pre-laying phase.
\end{abstract}

Key Words: bone resistance, nutritional requirement, quail nutrition

\section{Introduction}

Investments in quail production in Brazil have increased due to the fact that some characteristics of these birds have become a profitable alternative in the Brazilian market. The increase in quail production has been highlighted over the last years. Its evolution has been constant and increasing numbers of poultry companies have expressed an interest in improving their product quality at a low cost and in meeting the needs of the consumer (Bertechini, 2009).

The market is expanding and, as a result, companies related to quail production need scientific information and data pertaining to nutrition, genetics, management, and ambience of meat-type quail to enhance their production.

An accurate determination of nutritional requirements is of great importance to all bird species, as diet is perhaps the main environmental factor that determines bird growth and allows them to reach their maximum genetic potential (Albino and Barreto, 2003).

Calcium deposition in the skeleton is greater during the grower phase. Thus, calcium content in the body of chicks

Received January 28, 2016 and accepted August 5, 2016.

Corresponding author: simaramm@yahoo.com.br

http://dx.doi.org/10.1590/S1806-92902016001100003

Copyright $\odot 2016$ Sociedade Brasileira de Zootecnia. This is an Open Access article distributed under the terms of the Creative Commons Attribution License (http://creativecommons.org/licenses/by/4.0/), which permits unrestricted use, distribution, and reproduction in any medium, provided the original work is properly cited. increases quickly in the starter stage, so that at the end of the first month of age the chicks have $80 \%$ of the total calcium of an adult bird (Edwards Jr, 2000).

As the majority of vitamins are not synthetized in large amounts enough to meet the body physiologic demands, these nutrients must be obtained from the diet. According to Combs Jr (2008), the vitamins: are essential, usually in minute amounts, for normal physiological function (i.e., maintenance, growth, development, and/or production); cause, by its absence or underutilization, a specific deficiency syndrome; and are not synthesized by the host in amounts adequate to meet normal physiological needs.

The most physiologically important function of vitamin $\mathrm{D}$ is in the homeostasis of $\mathrm{Ca}^{2+}$ and phosphate, which is affected by a multihormonal system involving the controlled production of $1,25(\mathrm{OH})_{2} \mathrm{D}_{3}$, which functions in concert with parathyroid hormone and calcitonin. Regulation of this system occurs at the points of intestinal absorption, bone mineral accretion and mobilization, and renal excretion (Combs Jr, 2008).

Therefore, an experiment was conducted to estimate calcium requirements and vitamin D supplementation levels needed to attain the maximum productive performance and bone development in meat-type quail between 15 and 35 days old.

\section{Material and Methods}

The work was conducted in accordance with ethical standards and approved by the Ethics and Biosafety 
Committee of the State University of Maringá (case no. 091/2012).

We kept 1,920 meat-type quail (Coturnix coturnix sp) between 15 and 35 days old in a conventional hangar divided into 48 boxes.

The experimental design was completely randomized in a $4 \times 4$ factorial scheme (four calcium levels: 0.42, $0.58,0.74$, and $0.90 \% \mathrm{Ca}$ and four vitamin D levels: 1,000 ; 2,000; 3,000; and 4,000 IU) with a total of 16 treatments, three repetitions, and 40 quail per experimental unit.

An adequate number of repetitions can increase the experimental precision and therefore improve the capacity of a statistical test to detect small differences among estimates of a mean treatment (Velini et al., 2006). On a practical note, Pimentel-Gomes (2000) suggested that an experiment must be designed to provide a minimum of ten degrees of freedom per residue.

Data regarding the temperature was collected early in the morning and in the late afternoon during all experimental periods by using a maximum and minimum thermometer. The average temperature of the experimental period was $22{ }^{\circ} \mathrm{C}$.

The experimental diets were formulated based on ground corn and soybean meal, while the different calcium contents in the diet were obtained by varying the amount of inert limestone, calcium phosphate, and kaolin (Table 1).

To supply the required phosphorus in this study, we adopted the recommendation of Silva et al. (2009) of $4.1 \mathrm{~g} / \mathrm{kg}$ available $\mathrm{P}$.

The experimental diets were formulated to meet the requirements proposed by Rostagno et al. (2011) for broilers in the starter phase from 1 to 21 days of age, with the exception of calcium and vitamin D. The chemical composition and energy values of feeds were obtained from Rostagno et al. (2011).

Quails were weighed weekly to evaluate performance, while the experimental diets were weighed to determine feed intake (FI) (g/bird), body weight (BW) (g), body weight gain (WG) (g), and feed conversion (FC) (g feed/g gain).

Two quail (one male and one female) per experimental unit were used to determine carcass yield at 35 days of age.

Two quail per experimental unit were chosen for evaluation of bone parameters.

The femur and tibia were weighed using a precision scale and the length was measured with a digital caliper ruler to determine the Seedor index (Seedor et al., 1996).

Seedor index $=$ bone weight $(\mathrm{mg}) /$ length $(\mathrm{mm})$

The bones were immersed in petroleum ether for $24 \mathrm{~h}$ to be defatted. Afterwards, they were dried in a forced-air oven at $55^{\circ} \mathrm{C}$ for $72 \mathrm{~h}$.
The radiographic optical density was determined at a dental clinic.

First, the bones were placed in the same position under a film (Kodak Intraoral E-Speed Film, size 2, periapical type) and were radiographed using the X-ray dental appliance DabiAtlante ${ }^{\circledR}$, model Spectro 70X electronic (DabiAtlante, Ribeirão Preto, São Paulo, Brazil). The appliance operated at $70 \mathrm{kVp}, 8 \mathrm{~mA}$, with a 0.2 -s exposure time, determined by a previous pilot test, containing a stepwedge, focusing the X-ray beam perpendicularly to the film at a focus-film distance of $10 \mathrm{~cm}$.

After that, the radiographic films were processed using an automatic processing machine (Revel Industry and Equipment Trade Ltd.) with a work time of $150 \mathrm{~s}$ and operating with Kodak RP X-Omat solutions.

In a second step, the radiographic films were scanned into the Image Tool $^{\circledR}$ program (version 3.0, University of Texas Health Science Center at San Antonio, UTHSCSA, EUA, ftp://maxrad6.uthscsa.edu/) and recorded in files with a progressive JPG extension.

Table 1 - Composition of the basal diet offered to quail during the second growth stage

\begin{tabular}{lc}
\hline Diet & Quantity $(\mathrm{g} / \mathrm{kg})$ \\
\hline Corn & 489.5 \\
Soybean meal $(45 \%)$ & 418.3 \\
Soybean oil & 45.2 \\
Monocalcium phosphate & 14.4 \\
Vitamin D3 $^{1}$ & 1.0 \\
Limestone $^{\text {inert substance }}{ }^{2}$ & 14.0 \\
Vitamin and mineral premix & \\
Salt & 4.0 \\
DL-met & 4.0 \\
L-lysine HCL & 4.3 \\
L-threonine & 3.6 \\
Antioxidant & \\
Calculated values & 1.6 \\
Metabolizable energy $(\mathrm{mJ} / \mathrm{kg})$ & 0.1 \\
Crude protein $(\mathrm{g} / \mathrm{kg})$ & \\
Available P $(\mathrm{g} / \mathrm{kg})$ & 12.711 \\
Digestible lysine $(\mathrm{g} / \mathrm{kg})$ & 235 \\
Digestible methionine $+\mathrm{cystine}(\mathrm{g} / \mathrm{kg})$ & 4.1 \\
Digestible threonine $(\mathrm{g} / \mathrm{kg})$ & 14.5 \\
Digestible tryptophan $(\mathrm{g} / \mathrm{kg})$ & 10.4 \\
Cl $(\mathrm{g} / \mathrm{kg})$ & 9.4 \\
Na $(\mathrm{g} / \mathrm{kg})$ & 2.7 \\
$\mathrm{~K}(\mathrm{~g} / \mathrm{kg})$ & 2.8 \\
\hline
\end{tabular}

${ }^{1}$ Vitamin D3 $(500,000 \mathrm{IU} / \mathrm{g})$ was diluted with rice straw to achieve desired levels $(1,000 ; 2,000 ; 3,000 ;$ or $4,000 \mathrm{IU} / \mathrm{kg}$ diet $)$.

${ }^{2}$ Used $14.0 \mathrm{~g}$ inert substance (Kaolin, Nucleopar, Mandaguari, Brazil) $+0 \mathrm{~g}$ limestone, $9.8 \mathrm{~g}$ inert substance $+4.2 \mathrm{~g}$ limestone, $5.6 \mathrm{~g}$ inert substance $+8.4 \mathrm{~g}$ limestone, and $1.4 \mathrm{~g}$ inert substance $+12.6 \mathrm{~g}$ limestone to achieve dietary Ca concentrations of $0.42,0.58,0.74$, and $0.90 \% \mathrm{Ca}$, respectively.

${ }^{3}$ Vitamin/mineral premix (guaranteed levels per $\mathrm{kg}$ of product): retinol acetate, $700,000 \mathrm{IU}$; dl- $\alpha$-tocopheryl acetate, $6,250 \mathrm{IU}$; thiamine hydrochloride, $350 \mathrm{mg}$; riboflavin, $1,250 \mathrm{mg}$; pyridoxine hydrochloride, $600 \mathrm{mg}$; cyanocobalamin, $3,000 \mathrm{mcg}$; menadione nicotinamide bisulphite, $600 \mathrm{mg}$; D-calcium pantothenate, 3,000 mg; niacin acid, $8,760 \mathrm{mg}$; folic acid, $175 \mathrm{mg}$; biotin, $17.5 \mathrm{mg}$; choline chloride, $75 \mathrm{mg}$; butylated hydroxytoluene, $1,000 \mathrm{mg}$; zinc oxide, $12.0 \mathrm{~g}$; ferrous sulfate, $12.5 \mathrm{~g}$; manganese sulfate, $14.5 \mathrm{~g}$; copper sulfate, $1,000 \mathrm{mg}$; potassium iodate, $250 \mathrm{mg}$; cobalt sulfate heptahydrate, $50 \mathrm{mg}$; sodium selenite, $62.5 \mathrm{mg}$; and excipient q.s., 1,000 g. ${ }^{4} \mathrm{BHT}$ - butylated hydroxytoluene. 
Afterwards, Adobe Photoshop CS6 software was utilized to read the radiographic films and to determine the bone density using the Histogram tool, which analyzes the radiographic density of a selected area that is distributed in a color scale, close to gray, and has 256 shades. The value 0 represents the color black while the value 256 represents the color white. Three central points with a fixed size $(10 \mathrm{px} \times 10 \mathrm{px})$ were selected from the bone and a mean was obtained. The central area was chosen because it is the same area in which the bone received the force required to break in the resistance assay.

An aluminum scale of 10 degrees, with 1-mm thickness between degrees, was utilized as a radiographic reference. The data obtained in gray values were converted to relative based on the aluminum thickness scale, while all data were compared to the third degree on this scale.

The bone resistance was analyzed in a press designed to test the compressive unconfined strength of cohesive soil samples and the values were expressed in kilogram force (kgf). The bones were placed in such a way as to support the epiphyseal region, whereas the central region did not have support. The anteroposterior position was chosen to prevent movement of the bone during the break time. The force was applied in the central region at the same point for all bones and the descent probe speed that applied the force was consistent $(5 \mathrm{~mm} / \mathrm{s})$ for all bones. We used a load of $500 \mathrm{~N}$ (Newton) for all samples.

After the bone resistance assay, the left femurs were ground and dried in a forced-air oven. The samples were then weighed using an analytical scale (0.0001 g) and dried in an oven at $105^{\circ} \mathrm{C}$ for $12 \mathrm{~h}$ to determine the calcium and phosphorus contents in the bone, using the methodology described by Silva and Queiroz (2002).

The data were analyzed using the Statistical Analysis and Genetic System Program - SAEG (version 9.1) from the Federal University of Viçosa.

First, calcium and vitamin D requirements were estimated by a quadratic model or a discontinuous linear response plateau according to the adjustment data for each variable.

Results were obtained from the response surface analysis, which is a collection of mathematical and statistical techniques used to analyze problems pertaining to the influence of independent variables on responsedependent variables, with the ultimate goal of optimizing responses (Montgomery, 2009).

\section{Results}

No interaction was observed $(\mathrm{P}>0.05)$ between FI, as a function of calcium, and vitamin $\mathrm{D}$ levels in quail between
15 and 35 days of age. Only vitamin D levels caused a linear increase in FI (Table 2).

We observed $(\mathrm{P}<0.05)$ a linear increase in calcium and vitamin $\mathrm{D}$ requirements regarding the variables $\mathrm{BW}$, weight gain (WG), and FC.

Calcium and vitamin $\mathrm{D}$ levels did not affect $(\mathrm{P}>0.05)$ phosphorus content in the bone, tibial bone resistance, or bone densitometry (Table 3 ).

Calcium levels in the diet did not affect $(\mathrm{P}>0.05)$ calcium and ash contents in the bones, while vitamin $D$ had a quadratic effect $(\mathrm{P}<0.05)$ on the same parameters, for estimated levels of 2,712 and 2,700 IU of vitamin D, respectively.

The femoral Seedor index increased linearly $(\mathrm{P}<0.05)$ due to calcium levels, while a quadratic effect $(\mathrm{P}<0.05)$ was observed as a result of vitamin D levels, with an estimated level of 2,756 IU of vitamin D. The tibial Seedor index and femoral bone resistance increased linearly $(\mathrm{P}<0.05)$ with increased levels of dietary calcium

The blood calcium levels (BLC) increased linearly $(\mathrm{P}<0.05)$ with the increase in dietary calcium levels and a quadratic effect $(\mathrm{P}<0.05)$ was observed with the increase in vitamin $\mathrm{D}$ (VD) according to the following equation: $\mathrm{BLC}=5.86509-6.77668 \times \mathrm{Ca}+0.00457851 \times \mathrm{VD}-$ $0.000000976975 \times \mathrm{VD}^{2}\left(\mathrm{R}^{2}=0.91\right)$, with an estimated level of 2,343 IU of vitamin D (Table 3).

Calcium and vitamin $\mathrm{D}$ levels did not have significant effects $(\mathrm{P}>0.05)$ on carcass and cut yields. However, the same pattern was observed with WG and BW (Table 2) such that calcium and vitamin D levels led to a linear increase $(\mathrm{P}<0.05)$ in carcass weight, breast weight, and leg weight.

\section{Discussion}

According to Silva and Costa (2009), the calcium supplementation requirement for Japanese quail from 22 to 42 days of age is $0.50 \%$, while for European quail the requirement is $0.70 \%$, in diets containing $3,050 \mathrm{kcal}$ of metabolizable energy $(\mathrm{ME}) / \mathrm{kg}$ and $22 \%$ crude protein (CP). However, Rostagno et al. (2011) recommended $0.90 \%$ calcium for Japanese quail in the starter and grower phases, while there was no recommendation reported for vitamin $\mathrm{D}$.

The INRA (1999) tables stated that the calcium requirement is $0.85,0.90$, and $0.95 \% \mathrm{Ca}$ in diets containing 2,800; 3,000; and 3,200 kcal of ME/ kg and 23.0, 24.6, and $26.3 \%$ CP, respectively. Moreover, the NRC (1994) reported a requirement of $0.80 \% \mathrm{Ca}$ in diets containing 2,900 kcal of $\mathrm{ME} / \mathrm{kg}$ and $24 \% \mathrm{CP}$. The experimental diet was formulated to contain $3,036 \mathrm{kcal}$ of $\mathrm{ME} / \mathrm{kg}$ and $23.5 \% \mathrm{CP}$. 


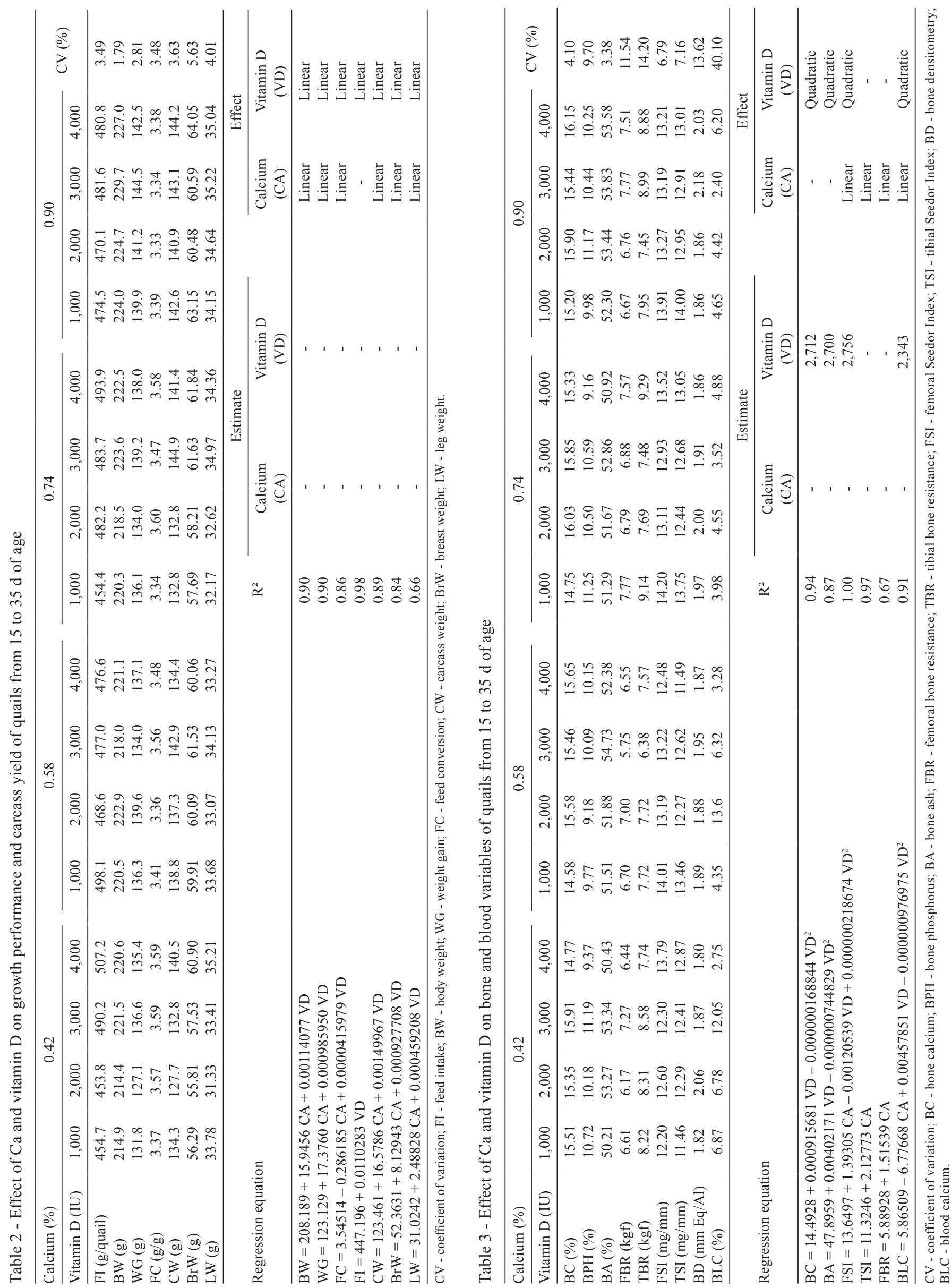


Some studies indicate that sexual maturity in quail occurs between 35 and 42 days of age. According to Classen and Scott (1982), calcium intake increases at slower rates before the first oviposition, which is probably a result of the high amount of calcium required to develop the medullary bone, which begins forming in response to sexual hormones.

This may explain the linear increase in calcium and vitamin $\mathrm{D}$ requirements in quail between 15 and 35 days of age. Keshavarz (1987) suggested an alternative method to decrease calcium requirements of medullary formation and to increase calcium storage levels in the bone. $\mathrm{He}$ proposed that increasing the calcium levels during the preoviposition period could decrease egg production, because low calcium levels could reduce the actions of follicle stimulating hormone (Taher et al., 1984).

Diets with high-calcium content yield greater amounts of available calcium in the gut and as a result, birds have enough calcium to meet normal growth standards and have enough calcium stored in the bone to utilize during the oviposition period (Vargas Jr. et al., 2004). Thus, calcium storage can be used during the oviposition period when calcium demand is high.

Leeson et al. (1986) evaluated birds that were fed diets with low-calcium content during the pre-oviposition period and observed that birds had impaired egg production when fed low-calcium diets for long periods. However, egg production normalized when calcium stores in the bone were restored.

Another factor that may be related to the linear increase of vitamin D requirements is the immunomodulatory effect of vitamin D. Klasing (1998) relayed that the immune system has a greater priority for nutrients and is able to compete with other tissues depending on the nutrient levels and the feed ingredients.

Calcium and ash contents in the bone were not affected by the increase in calcium and vitamin D levels, because they were probably being mobilized to maintain the blood calcium levels, since they were crescent, because the bones are metabolically active tissues.

The results showed that calcium levels were associated with a linear increase in diameter, length, weight, and fill of bone organic matrix because Seedor index and bone resistance were influenced by these variables.

Some authors (Alves et al., 2002; Driver et al., 2005; Bertechini, 2006) found that the reduction in dietary calcium improves the efficiency of calcium absorption due to the regulation of 1,25-Dihydroxycolecalciferol in both plasma and intestine (Morrissey and Wasserman, 1971; Montecuccolli et al., 1977). Furthermore, an increase in the concentration of duodenal calbindin, a protein found in the intestine that binds calcium from the lumen (Hunziker et al., 1982), also helps to increase absorption.

The use of calcium stores from the medullary bones to support egg production leads to a sudden loss of $2 \mathrm{~g}$ of body calcium. Thus, calcium stores in the bones are needed prior to the production period. Thus, significant calcium levels should be provided in the diets for the preoviposition period (Lesson and Summers, 2005).

Regarding calcium and vitamin D supplementation in growing meat-type quail, it can be concluded that it is not ideal to compare quail and broiler physiology or age, because quail begin to produce eggs soon after the grower stage.

\section{Conclusions}

The supplementary levels of calcium and vitamin D in meat-type quail between 15 and 35 days of age required for maximum growth and performance is greater or equal to $0.90 \%$ of calcium and equal to $4,000 \mathrm{IU}$ of vitamin D; these results may be due to the greater nutrient requirements during the pre-oviposition stage.

\section{References}

Albino, L. F. T. and Barreto, S. L. T. 2003. Criação de codornas para produção de ovos e carne. Aprenda Fácil, Viçosa, MG.

Alves, E. L.; Teixeira, A. S.; Bertechini, A. G.; Rodrigues, P. B. and Oliveira, A. I. G. 2002. Efeito dos níveis de cálcio em duas fontes sobre o desempenho de frangos de corte. Ciência e Agrotecnologia 26:1305-1312

Bertechini, A. G. 2006. Nutrição de monogástricos. Editora UFLA, Lavras.

Beterchini, A. G. 2009. Como estão as codornas? In: Avicultura industrial. Available at: $<\mathrm{http}: / / \mathrm{www}$. aviculturaindustrial.com.br/ portalgelissulli/noticias.htm>. Accessed on: Jan. 21, 2013.

Classen, H. L. and Scott, T. A. 1982. Self-selection of calcium during the rearing and early laying periods of White Leghorn pullets. Poultry Science 61:2065-2074.

Combs Jr, G. F. 2008. The vitamins: Fundamental aspects in nutrition and health. Elsevier Academic Press, New York.

Driver, J. P.; Pesti, G. M.; Bakalli, R. I. and Edwards Jr., H. M. 2005. Calcium requirements of the modern broiler chicken as influenced by dietary protein and age. Poultry Science 84:1629-1639.

Edwards Jr, H. M. 2000. Nutrition and skeletal problems in poultry. Poultry Science 79:1018-1023.

Hunziker, W.; Walters, M. R.; Bishop, J. E. and Norman, A. W. 1982. Effect of vitamin D status on the equilibrium between occupied and unoccupied 1,25- dihydroxyvitamin D intestinal receptors in the chick. Journal of Clinical Investigation 69:826-834.

INRA - Institut National de la Recherche Agronomique. 1999. Alimentação dos animais monogástricos: suínos, coelhos e aves. Roca, São Paulo.

Keshavarz, K. 1987. Influence of feeding a high calcium diet for various durations in prelaying period on growth and 
subsequent performance off white leghorn pullets. Poultry Science 66:1576-1582.

Klasing, K. C. 1998. Nutritional modulation of resistance to infectious diseases. Poultry Science 77:1119-1125.

Leeson, S.; Julian, R. J. and Summers, J. D. 1986. Influence of prelay and early-lay dietary calcium concentration on performance and bone integrity of leghorn pullets. Canadian Journal of Animal Science 66:1087-1095.

Leeson, S. and Summers, J. D. 2005. Commercial poultry nutrition. Guelf, Ontario.

Montecuccoli, G.; Hurwitz, S.; Cohen, A. and Bar, A. 1977. The role of 25-hydroxycholecalciferol-1-hydroxylase in the responses of calcium absorption to the reproductive activity in birds. Comparative Biochemistry and Physiology Part A: Physiology 57:335-339.

Montgomery, D. C. 2009. Design and analysis of experiments. John Wiley \& Sons, New York.

Morrissey, R. L. and Wasserman, R. H. 1971. Calcium absorption and calcium-binding protein in chicks on differing calcium and phosphorus intakes. American Journal of Physiology 220:1509-1515.

NRC - National Reserch Council. 1994. Nutrient requirements of poultry. National Academy of Sciences, Washington, DC.

Pimentel-Gomes, F. 2000. Curso de estatística experimental. Fealq, Piracicaba.
Rostagno, H. S.; Albino, L. F. T.; Donzele, J. L.; Gomes, P. C.; Oliveira, R. F.; Lopes, D. C.; Ferreira, A. S.; Barreto, S. L. T. and Euclides, R. F. 2011. Tabelas brasileiras para aves e suínos: composição de alimentos e exigências nutricionais. Editora UFV, Viçosa, MG.

Seedor, T.; Watanabe, E. and Kadowaki, W. 1996. Effect of dietary and arginine levels on bone development in broiler chicks. Animal Science and Technology 67:7-13.

Silva, D. J. and Queiroz, A. C. 2002. Análises de alimentos (métodos químicos e biológicos). Editora UFV, Viçosa, MG.

Silva, J. H. V. and Costa, F. G. P. 2009. Tabela para codornas japonesas e européias. FUNEP, Jaboticabal.

Silva, R. M.; Furlan, A. C.; Ton, A. P. S.; Martins, E. N.; Scherer, C. and Murakami, A. E. 2009. Exigências nutricionais de cálcio e fósforo de codornas de corte em crescimento. Revista Brasileira de Zootecnia 38:1509-1517.

Taher, A. I.; Gleaves, E. W. and Beck, M. 1984. Special calcium appetite in laying hens. Poultry Science 63:2261-2267.

Vargas Jr., J. G.; Albino, L. F. T.; Rostagno, H. S.; Gomes, P. C.; Carvalho, D. C. O.; Cupertino, E. S.; Toledo, R. S. and Pinto, R. 2004. Níveis nutricionais de cálcio e de fósforo disponível para aves de reposição leves e semipesadas de 13 a 20 semanas de idade. Revista Brasileira de Zootecnia 33:1263-1273.

Velini, E. D.; Palma, V.; Souza, L. S. and Martins, D. 2006. Interferência de plantas daninhas na cultura do milho. I - Efeito do número de repetições sobre a precisão dos resultados obtidos. Planta Daninha 24:435-442. 